www.jmscr.igmpublication.org

Index Copernicus Value: 79.54

ISSN (e)-2347-176x ISSN (p) 2455-0450

crossref DOI: https://dx.doi.org/10.18535/jmscr/v7i5.36

Journal Of Medical Science And Clinical Research

IGM Publication

An official Publication of IGM Publication

\title{
A Cross-Sectional Study to Assess the Prevalence of Psychosocial Problems Among Geriatric Age Group of All the Three Strata of Social Class in Central India
}

\author{
Authors \\ Sunil K Guleri, Shraddha Mishra \\ Department of Community Medicine, Bundelkhand Medical College Sagar, Madhya Pradesh, India \\ *Corresponding Author \\ Dr Shraddha Mishra \\ Department of Community Medicine, Bundelkhand Medical College Sagar, Madhya Pradesh, India \\ Email: dr.shraddhamishra@yahoo.com, Contact No.: 9424616454
}

\begin{abstract}
Common psychosocial problems of geriatric population are depression, dementia, loneliness, social insecurity, economic instability, sleep disturbances, irritability, etc. The four major psychosocial problems considered in our study are Dementia, depression, loneliness and sleep disorders. WHO report of 2004 states that 536 elderly people per 10,000 suffer from physical and psychosocial problems of old age. The study started with identification of slum areas, residential colonies and pos developed societies in the city sagar, so that sufficient subjects can be identified from low, middle and high socioeconomic class. The identified areas were surveyed till 30 elderly of age 60 years and above (15 males and 15 females) were identified from each classified areas. A pretested semi structured questionnaire was used to assess psychosocial issues of elderly. Prevalence of depression was higher in lower socioeconomic class compared to the middle and higher classes. Females from low socioeconomic status had highest prevalence of having possible early Dementia while males belonging to low socioeconomic class are least likely to be affected with possible early dementia when compared to other classes, The loneliness index of females belonging to low socio-economic status group is highest $49.13 \%$ among all classes. The overall level of psychosocial problems was higher in Lower socioeconomic class when compared to middle and higher socioeconomic class. The burden of psychosocial problems, considered in our study viz. Dementia, depression, loneliness and sleep disorders, was more in female section of the geriatric population as compared to males.

Keywords: geriatric, psychosocial problems, socioeconomic class, loneliness.
\end{abstract}

\section{Introduction}

Ageing is a natural phenomenon and has its own dynamics, which is beyond human control. The elderly population is growing faster than the total population throughout the world. The proportion of the elderly population in India rose from $5.6 \%$ in 1961 to $7.5 \%$ in 2001 and it will rise to $9 \%$ by 2016. ${ }^{[1]}$ The Indian elderly population is currently the second largest in the world. ${ }^{[2]}$ Common psychosocial problems of geriatric population are depression, dementia, loneliness, social insecurity, economic instability, sleep disturbances, 
irritability, etc. The four major psychosocial problems considered in our study are Dementia, depression, loneliness and sleep disorders. India is currently experiencing epidemiological transition of diseases from phase of more morbidity due to communicable diseases towards non communicable diseases wherein psychosocial problems are creating a major component of hidden disability. WHO report of 2004 states that 536 elderly people per 10,000 suffer from physical and psychosocial problems of old age. Another WHO report alarms that, by 2025, around 4 million Indians will be suffering from Dementia. ${ }^{[3]}$

\section{Dementia}

Dementia is a syndrome in which there is deterioration in memory, thinking, behaviour and the ability to perform everyday activities. Worldwide, 47.5 million people have dementia and there are 7.7 million new cases every year. Dementia is one of the major causes of disability and dependency among older people worldwide. [4],[5] Loneliness: Loneliness is a complex and usually unpleasant emotional response to isolation or lack of companionship. Loneliness typically includes anxious feelings about a lack of connectedness or communality with other beings, both in the present and extending into the future. Loneliness has also been described as social pain - a psychological mechanism meant to alert an individual of isolation and motivate him/her to seek social connections. ${ }^{[6]}$ loneliness in the community can be assessed using Revised UCLA scale of loneliness (Russell et al, 1980) ${ }^{[6]}$ : it includes 10 negatively worded and 10 positively worded items that have highest correlations with the questions that are related to loneliness. The revised loneliness scale has a high internal consistency with a coefficient alpha of $0.9^{[6]}$.

\section{Depression}

Depression is a common mental disorder. Globally, an estimated 350 million people of all ages suffer from depression. Depression is the leading cause of disability worldwide, and is a major contributor to the overall global burden of disease. At its worst, depression can lead to suicide. The geriatric depression scale (GDS)-15 is designed specifically to screen depression among elderly. It can be used as a valid public health instrument, which can be easily acceptable for detecting and managing depression in non specialized settings. Further a short form of Geriatric Depression Scale with 15 question (GDS-15) is also available for rapid assessment. ${ }^{[7]}$ Sleep disorder: A sleep disorder, or somnipathy, is a medical disorder of the sleep patterns of a person. Some sleep disorders are serious enough to interfere with normal physical, mental, social and emotional functioning. When a person suffers from difficulty falling asleep and/or staying asleep with no obvious cause, it is referred to as insomnia. Sleep disorders are broadly classified into dyssomnias, parasomnias, circadian rhythm sleep disorders involving the timing of sleep, and other disorders including ones caused by medical or psychological conditions and sleeping sickness. Insomnia may be defined if it includes at least one instance of difficulty initiating sleep $(8.3 \%)$, maintaining sleep (15.0\%), or early morning awakening $(8.0 \%){ }^{[8]}$

The study was done with an objective to identify any effect of socioeconomic class on prevalence of different psychosocial problems in elderly. Mostly these problems are attributed to growing older but role of society, life style and behaviour of elderly and his family members in different socioeconomic strata was to be studied.

\section{Material \& Methods}

This is a cross sectional observational study done in Sagar city of Madhya Pradesh in India, on elderly people of age 60 and above. Sample size of 30 elderly people based on 30 cluster sampling method was used in this study. Slums, residential colonies (low income and middle income groups) and highly developed pos areas of high income group were identified and listed. The socioeconomic status of elderly was verified based on modified B G Prasad scale. Due to lack of data of exact population of elderly in different wards , 
slums etc active survey was done in all three types of classified areas to get 30 elderly people who were ready to participate in the study and given their consent. Thus a total of 90 elderly were included in the study where $50 \%$ of the subjects were elderly female. Genetic depression scale (short form) with 15 questions was administered for assessment of depression. A pre designed, pre tested semi structured questionnaire derived from the revised-UCLA (University Of California Los Angles) scale of loneliness with biographical data and possible health consequences (diet, sleep, stress, headache and depression) was administered for assessment of loneliness. A semi structured questionnaire was developed to assess the presence of dementia and sleep disorders. The data so collected in excel spread sheets and was analysed using SPSS software.

\section{Results}

Prevalence of depression was seen higher in lower socioeconomic class as compared to the middle and higher, $80 \%$ Females of low socio-economic class had depression which is highest, while only $20 \%$ males of high socio-economic status are having depression. Table 1 Females from low socioeconomic status are the one having highest percentage i.e. $100 \%$ of them were having possible early Dementia while males belonging to low socioeconomic class are least likely to be affected with possible early dementia when compared to other classes. Table $25.86 \%$ Females belonging to Low socio-economic status group were having sleep disorder score which is highest and indicating poorer quality of sleep when compared with other classes while males belonging to Middle Socio-economic status group were having lowest i.e. 3.2\% sleep disorder score indicating better quality of sleep when compared with other classes. Table 3 The loneliness index of females belonging to low socio-economic status group is highest among all classes $49.13 \%$ the loneliness index of males belonging to high socio-economic status group is lowest among all classes $44.99 \%$.

Table 4

Table 1: Distribution of depression in elderly people of different socioeconomic status

\begin{tabular}{|c|c|c|c|c|c|c|}
\hline S. No. & Category & Gender & $\begin{array}{c}\text { Total } \\
\text { subject }\end{array}$ & Number & $\begin{array}{l}\% \text { having } \\
\text { depression }\end{array}$ & $\begin{array}{c}\text { Total } \\
\text { percentage }\end{array}$ \\
\hline \multirow[t]{2}{*}{1.} & \multirow{2}{*}{$\begin{array}{c}\text { Low } \\
\text { socio economic } \\
\text { status }\end{array}$} & Female & 15 & 12 & 80 & \multirow[t]{2}{*}{66.66} \\
\hline & & Male & 15 & 8 & 53.33 & \\
\hline \multirow[t]{2}{*}{2.} & \multirow{2}{*}{$\begin{array}{c}\text { Middle } \\
\text { socio economic } \\
\text { status }\end{array}$} & Female & 15 & 13 & 86.6 & \multirow[t]{2}{*}{63.3} \\
\hline & & Male & 15 & 6 & 40 & \\
\hline \multirow[t]{3}{*}{3.} & \multirow{2}{*}{$\begin{array}{c}\text { High } \\
\text { socio economic } \\
\text { status }\end{array}$} & Female & 15 & 4 & 26.66 & \multirow[t]{2}{*}{23.33} \\
\hline & & Male & 15 & 3 & 20 & \\
\hline & Total & & 90 & 46 & 51.1 & \\
\hline
\end{tabular}

Table 2: Distribution of sleep disorders index in elderly people of different socioeconomic status

\begin{tabular}{|c|c|c|c|c|c|}
\hline S. No. & Category & Gender & $\begin{array}{c}\text { Total } \\
\text { subject }\end{array}$ & $\begin{array}{l}\text { Presence of Sleep } \\
\text { disorder (no.) }\end{array}$ & Percentage \\
\hline \multirow[t]{2}{*}{1.} & \multirow{2}{*}{$\begin{array}{l}\text { Low socio economic } \\
\text { status }\end{array}$} & Female & 15 & 8 & \multirow[t]{2}{*}{$50 \%$} \\
\hline & & Male & 15 & 7 & \\
\hline \multirow[t]{2}{*}{2.} & \multirow{2}{*}{$\begin{array}{l}\text { Middle socio economic } \\
\text { status }\end{array}$} & Female & 15 & 6 & \multirow[t]{2}{*}{$30.6 \%$} \\
\hline & & Male & 15 & 5 & \\
\hline \multirow[t]{3}{*}{3.} & \multirow{2}{*}{$\begin{array}{l}\text { High socio economic } \\
\text { status }\end{array}$} & Female & 15 & 5 & \multirow[t]{2}{*}{$30.6 \%$} \\
\hline & & Male & 15 & 6 & \\
\hline & Total & & 90 & 37 & $40.1 \%$ \\
\hline
\end{tabular}


Table 3: Distribution of dementia in elderly people of different socioeconomic status

\begin{tabular}{|c|c|c|c|c|c|c|}
\hline S. no. & Category & $\begin{array}{c}\text { Sub } \\
\text { category }\end{array}$ & $\begin{array}{c}\text { Total } \\
\text { subjects }\end{array}$ & $\begin{array}{c}\text { Subjects } \\
\text { with } \\
\text { dementia }\end{array}$ & $\begin{array}{l}\% \text { of subjects } \\
\text { with dementia }\end{array}$ & $\begin{array}{c}\text { Total } \\
\text { percentage }\end{array}$ \\
\hline \multirow[t]{2}{*}{1} & \multirow{2}{*}{$\begin{array}{c}\text { Low } \\
\text { socio economic } \\
\text { status }\end{array}$} & Female & 15 & 15 & 100 & \multirow[t]{2}{*}{66.66} \\
\hline & & Male & 15 & 5 & 33.33 & \\
\hline \multirow[t]{2}{*}{2} & \multirow{2}{*}{$\begin{array}{c}\text { Middle socio } \\
\text { economic } \\
\text { status } \\
\end{array}$} & Female & 15 & 13 & 86.66 & \multirow{2}{*}{79.95} \\
\hline & & Male & 15 & 11 & 73.33 & \\
\hline \multirow[t]{3}{*}{3} & \multirow{2}{*}{$\begin{array}{c}\text { High } \\
\text { socio economic } \\
\text { status }\end{array}$} & Female & 15 & 12 & 80 & \multirow[t]{2}{*}{66.66} \\
\hline & & Male & 15 & 8 & 53.33 & \\
\hline & Total & & 90 & 64 & 70.1 & \\
\hline
\end{tabular}

Table 4: Distribution of loneliness in elderly people of different socioeconomic status

\begin{tabular}{|c|c|c|c|c|c|}
\hline S.no. & Category & Sub category & $\begin{array}{c}\text { Total } \\
\text { subject }\end{array}$ & $\begin{array}{c}\text { Average } \\
\text { loneliness } \\
\text { index }\end{array}$ & $\begin{array}{c}\text { Loneliness index } \\
\text { aggregated }\end{array}$ \\
\hline \multirow[t]{2}{*}{1} & \multirow{2}{*}{$\begin{array}{c}\text { Low socio economic } \\
\text { status }\end{array}$} & Female & 15 & 49.13 & \multirow[t]{2}{*}{47.095} \\
\hline & & Male & 15 & 45.06 & \\
\hline \multirow[t]{2}{*}{2} & \multirow{2}{*}{$\begin{array}{l}\text { Middle socio } \\
\text { economic } \\
\text { status }\end{array}$} & Female & 15 & 46.06 & \multirow[t]{2}{*}{44.995} \\
\hline & & Male & 15 & 43.93 & \\
\hline \multirow[t]{3}{*}{3} & \multirow{2}{*}{$\begin{array}{c}\text { High socio economic } \\
\text { status }\end{array}$} & Female & 15 & 46.08 & \multirow[t]{2}{*}{45.30} \\
\hline & & Male & 15 & 44.53 & \\
\hline & Total & & 90 & 45.79 & \\
\hline
\end{tabular}

\section{Discussion}

The Constitution of India under the Article 41 mandates the well being of older persons and directs the state government to make effective provisions for securing the right to public assistance in old age, within the limits of its economic capacity and development. This study included 90 subjects, 45 males and 45 females. According to our study the overall percentage of early possible dementia is $71.09 \%$ in Geriatric population of our study group a similar study done by Maj. Raghunandan Mani Et al revealed that $4.1 \%$ of their subject population were having prevalence of dementia ${ }^{[9]}$ differences in the results are may be possible due to differences in the parameter considered in both studies, that is, dementia in the study conducted at Pune and possible early dementia in the present study.

The present study showed overall depression in $51.10 \%$ of subject population, $64.4 \%$ in Females and $37.77 \%$ in Males. While the study conducted by Sanjay Gupta Et al, showed depression in $9.6 \%$ population ${ }^{[10]}$. Another study in 2007 conducted by Jain RK et al showed depression in $45.9 \%$ study population and was more in females $(57.8 \%$, $\mathrm{p}<0.05) .{ }^{[1]}$ A third study published in 2013, done by Mr. R.S. Bharatwaj of Shree Laxmi Narayan Institute of Medical Sciences, Pondicherry, India revealed $98 \%$ suffering from depression of which $78 \%$ were having mild depression and $20 \%$ were with severe depression $^{[12]}$ Prevalence of severe depression among females was higher $(24.5 \%)$ than males (14.8\%). All the mentioned studies have shown differences in the results pertaining to Depression among geriatric population. These differences may be due to different sample populations and due to different scales and parameters considered in them for depression. But results have been consistent in classifying females as having overall more depression as compared to males. Another study in south India found prevalence of depression assessed by using Kannada version of GDS-15 among 100 elderly was found to be 36 $(36 \%)$ and $23(41.1 \%)$ of the females were having depression. ${ }^{[13]}$ 
This study summarized that the overall average loneliness score is 45.79. The score is higher (47.09) in female subjects as compared to males (44.50). A study conducted by Ubeidulla Et al in Nanded Dist. Maharashtra showed $42 \%$ subjects had feeling of loneliness and loneliness was seen in $21.05 \%$ males and $27.3 \%$ in Females reflecting higher prevalence of loneliness in females ${ }^{[14]}$.

The results of above similar to that of the present study, as both the studies have found more Loneliness among females as compared to male. The present study showed that average score of sleep disorder is 4.18 in overall study population. It was higher in females with a score of 4.88 and lower in males with score of 3.48. The study conducted by Ubeidulla Et al in Nanded Dist. Maharashtra showed that $68 \%$ subjects had disturbed sleep pattern ${ }^{[14]}$.

\section{Conclusion}

The present study showed that there were significant psychosocial problems among the geriatric age group population. The overall level of psychosocial problems was higher in Lower socioeconomic class when compared to middle and higher socioeconomic class. The burden of psychosocial problems, considered in our study viz. Dementia, depression, loneliness and sleep disorders, was more in female section of the geriatric population as compared to males, irrespective of their socioeconomic class. Thus the study brings to light the urgent need of interventions for improving the quality of life of this growing segment of population.

Source of support: nil

\section{References}

1. Kandpal SD, Kakkar R, Aggarwal P. Mental and social dimensions in geriatric population: Need of the hour. Indian J Community Health 2012;24:71-2.

2. The World Health Organization. Mental Health. Available from: http://www.who.org. [Last cited on 2013 Aug 12].

3 Situational Analysis of Elderly in India. Central Statistics Office Ministry of Statistics \& Programme Implementation Government of India, June 2011

4 Tools for Early Identification, Assessment, and Treatment for People with Alzheimer's disease and Dementia. National Chronic Care Consortium and the Alzheimer's Association, June 2003.

5 Sunderland T, Minichiello M. Dementia mood assessment scale. International psycho geriatrics, 1996; 8(3):331-333.

6 Russell, D, Peplau L.A., \& Cutrona, C.E. (1980). The revised UCLA Loneliness Scale: Concurrent and discriminated validity evidence. Journal of Personality and Social Psychology, 39, 472-480.

7 Sheikh JI, Yesavage JA. Geriatric Depression Scale (GDS): recent evidence and development of a shorter version. Clin Gerontol. 1986 June;5(1/2):165-173.

8 Kim K, Uchiyama M, Okawa M, Liu X, Ogihara R. An epidemiological study of insomnia among the Japanese general population. Sleep. 2000; 23:41-7.

9 Saldanha D, Mani M R , Srivastava K, Goyal S , Bhattacharya D. An epidemiological study of dementia under the aegis of mental health program, Maharashtra, Pune chapter. Indian J Psychiatry [serial online] 2010

10 Mawar S, Koul P, Das S, Gupta S. association of physical problems and depression with elder abuse in urban community of North India. Indian $\mathbf{J}$ Community Med . 2018;43:165-9

11 Jain $\mathrm{RK}^{1}$, Aras RY. Depression in geriatric population in urban slums of Mumbai. Indian J Public Health. 2007;51(2):112-3.

12 Bharatwaj RS, Vijaya K, and Rajaram P. Prevalence of urban geriatric depression: A cross sectional study in Pondicherry. Int J Med Health Sci 2013; 2:286-91. 
13 Sanjay TV, Jahnavi R, Gangaboraiah B, Lakshmi P, Jayanthi S Prevalence and factors influencing depression among elderly living in the urban poor locality of Bengaluru city. Int $\mathbf{J}$ health allied Sci 2014;3: 105-9

14 Ubaidulla M, Inamdar I.F., Aswar N.R, Doibale M.K., Narkhede M.G. Medical and Psychosocial Profile of Geriatric Population in Field Practice Area of Nanded, India. IOSR Journal of Dental and Medical Sciences (IOSR-JDMS)2014;13

(3) Ver. II. , PP 29-33. 